\title{
Effect of a Program using the Skills of Orientation and Movement at the Level of Sensory Sense of Movement and Some Gymnastics Skills of Blind Children "Prof Ass. Dr/ Najla Salama Mohammed
}

\section{Introduction and research problem}

The interest in childhood has become an inevitable necessity imposed by reality, especially in the first six years. At this stage, physical, mental, social and psychological development occurs. The child also acquires habits that are difficult to create later, and complex to change in later periods of his life.

And the human being since his childhood depends fundamentally on his life on all his senses that God has blessed him, and through these senses acquires the different sensations that are his experiences information the cognitive, intellectual and visual, so that the loss of sense of senses or weakness affects the accuracy of receiving stimuli and their translation and classification and response to her.

According to Samir AlYosr (2005), Farouk AlRousan (2001), and accordingly, if the concern for decent children is necessary, the education and education of children with special needs is a duty of the State in all its institutions and competent bodies. (14: 6) (69: 6), which will lead to an improvement in the abilities of these groups.

Perhaps one of the greatest direct effects of visual impairment is that the blindness of the blind person, The suffering of the blind from the difficulty of movement and the lack of freedom of movement in the vacuum. Said Mohammed Al-Said (2006) noted that the lack of freedom of movement negatively affects the entire growth process (5: 178)

Thus, the blind child, as noted by Auzter (2003), grows and is inexperienced. Therefore, all aspects of his growth are affected. He moves from sitting to standing directly without passing through the earth, and can be a picture of the place around him

"Assistant Professor, Artistic Gymnastics Training Department, Faculty of Physical Education for Girls, Helwan University. 
physically and over time. Spatial relationships can be understood and begin to have the correct spatial memory in the child $(13: 24,27$.)

The importance of playing as a basic need for a blind child in the first six years, and the need to develop his sense and growth, have been shown to be an important aspect of adjustment and guidance for this group of children. Emotional and dynamic (33: 25.)

Awatif Mohammed, Manal Abdel Fattah (2006) reported that the blind child's practice of the movement helps him to develop psychological and social abilities such as control, self-confidence, selfacceptance and social acceptance. Towards the self and toward others $(8: 26)$

The issue of orientation and movement is an important issue in the field of visual disability. It is the development or restructuring of the basic skills of independence in the field of movement as it is the center of the basic processes of the development of psychosocial skills.

The independent movement also facilitates the participation of the blind in all aspects of life. With a lot of work and access to social and recreational opportunities possible, as the inability to move and move in the environment limits the access to various services, in addition to the effects and health problems resulting from the deterioration of the efficiency of the body's organs, especially what blood circulation. (31:15) "The concept of orientation and movement includes two related terms. The first is the orientation and means the process of using the senses to enable the person to identify the focal point and its relation to all important things related to movement in a field and the second movement and means the readiness and ability of the person to move in this area (87: 7)

Huebner and Wiener (2005) point out that both orientation and movement are a combination that enables the blind to master the basic skills of life.

The movement is not just a move from one place to another but involves thinking and trying to connect a set of relationships between things and The places where the individual moves, so 
movement is an important and influential factor in the blind child's personality (579: 18)

In this regard, Ihab ElBeblawi (2011) points out that orientation and movement skills as well as communication skills and everyday life skills are essential skills that all blind children must learn because they will increase their ability to understand the surroundings and move within them Safely and independently. (15:3)

Gymnastics is one of the activities that includes different types suitable for childhood, such as gymnastics, gymnastics, gymnastics and gymnastics, and these types of gymnastics, which are performed in the form of simplified games and racing, and consists of games natural child favorite, and used for the development of the small child of It helps to increase the awareness of the body and the awareness of the movement and its concepts, and also to gain self-confidence and the spirit of collective performance and improve the basic skills, as well as strengthen the child and develop his senses and training (2:11)
And attention to the dynamic side of blind children requires the development of basic motor skills, which in turn requires the development of awareness in this group of children, because the cognitive heart of mental activity as explained by Mona Baroudi (2008) that the process of perception in the child begins sensory perception, And his skills through the cognitive connection that exists between him and his external world, and therefore the child acquires a certain cognitive method as a result of his interaction with others (9: $120-124)$

Nader Jaradat (2010) The high level of cognitivemotor cognition qualifies the individual to perform the motor skills accurately and efficiently, because the sensory receptors of the sensory-motor in the body are Which is responsible for changing and shaping the body's position and direction, as well as the relationship of its parts to each other (10:10)

The visual disability changes the way the child uses information about the world around him and limits his or her opportunities to learn by observing the elements and 
visual stimuli. This means that the blind child needs to learn special skills such as orientation and movement skills. Work in the field of gymnastics training for people with special needs The first years of the age of the visually impaired child, where there is a remarkable progress in motor abilities with the ability to learn motor skills is a stage of growth in which improved forms of movements known to improve significantly,

Which can be performed by the child so it is expected that this age is suitable for the exercise of basic motor skills and qualitative learning, especially that require the treatment of things or dealt with parties such as hand and man as well as the use of other parts of the body and those skills must evolve through various activities such as games and During the followup to the practical education of the students of the faculty in Cairo and the gymnasium clubs to note that the category of the disabled in general and visually impaired in particular found a lack of level of interest in that category despite the spread within the community and the right of disabled persons in the exercise of sports activities and During the work of the researcher in the training of gymnastics and found importance in the design of training programs for gymnastics skills for the disabled. Therefore, the researcher conducted this study to identify the impact of a program using the skills of orientation and movement at the level of sensory perception and some of the gymnastics skills of blind children

\section{Research goal}

The aim of the research is to identify the effect of a program using the skills of orientation and movement at the level of cognitive sense and some of the gymnastics skills of blind children

\section{Research hypotheses}

-There are statistically significant differences between the averages of pre and post measurements in the level of cognitive perception and some kinetic skills in the ground gymnastics of blind children experimental research group.

-There are statistically significant differences between the averages of the pre and post measurements in the level of cognitive perception and some kinetic skills in the ground 
gymnastics of blind children control group.

-There were statistically significant differences between the mean of the two dimensional measures in the experimental and control groups in sensory perception and some kinetic skills in the ground gymnastics of the blind children and for the experimental research group.

Research Plan and Procedures:

Research Methodology:

The researcher used the experimental method using the experimental design of two groups, one experimental and the other a control, in order to suit the nature of the research and to achieve its goals and hypotheses.

\section{Table (1)}

\section{Significance of differences between the control and experimental} groups In the variables in question $(\mathrm{N} 1=\mathbf{n} 2=10)$

\begin{tabular}{l|c|c|c|c|c|c}
\hline \multirow{2}{*}{ Variables } & \multirow{2}{*}{$\begin{array}{c}\text { Unit of } \\
\text { measure }\end{array}$} & \multicolumn{2}{|c|}{$\begin{array}{c}\text { Experimental } \\
\text { group }\end{array}$} & \multicolumn{2}{c|}{$\begin{array}{c}\text { Control } \\
\text { group }\end{array}$} & \multirow{2}{*}{ T } \\
\cline { 3 - 6 } & & $\mathbf{M}$ & $\mathbf{E}$ & $\mathbf{M}$ & $\mathbf{E}$ & \\
\hline \hline Age & Year & 5.11 & 0.22 & 5.17 & 0.21 & 0.63 \\
\hline Height & $\mathrm{Cm}$ & 95.52 & 1.65 & 94.62 & 2.11 & 0.11 \\
\hline Weight & $\mathrm{Kg}$ & 24.22 & 0.69 & 23.98 & 1.32 & 0.25 \\
\hline $\begin{array}{l}\text { ( Realize the direction } \\
\text { (walk in the corridor) }\end{array}$ & No & 4.25 & 0.39 & 4.21 & 0.69 & 0.39 \\
\hline Stability test & Time & 0.302 & 0.52 & 0.288 & 0.34 & 0.21 \\
\hline $\begin{array}{l}\text { Recognizing the direction of } \\
\text { the body during movement }\end{array}$ & No & 3.44 & 0.21 & 3.75 & 0.17 & 0.18 \\
\hline Recognizing body movement & No & 4.65 & 0.14 & 4.78 & 0.33 & 0.52 \\
\hline \hline
\end{tabular}

\section{Follow Table (1)}

Significance of differences between the control and experimental groups In the variables in question $(N 1=n 2=10)$

Assiut Journal For Sport Science Arts 


\begin{tabular}{l|c|c|c|c|c|c}
\hline \hline \multirow{2}{*}{ Variables } & \multirow{2}{*}{$\begin{array}{c}\text { Unit of } \\
\text { measure }\end{array}$} & \multicolumn{2}{|c|}{$\begin{array}{c}\text { Experimental } \\
\text { group }\end{array}$} & \multicolumn{2}{c|}{$\begin{array}{c}\text { Control } \\
\text { group }\end{array}$} & \multirow{2}{*}{$\begin{array}{c}\text { T } \\
\text { value }\end{array}$} \\
\cline { 3 - 6 } & & $\mathbf{M}$ & $\mathbf{E}$ & $\mathbf{M}$ & $\mathbf{E}$ & \\
\hline \hline Recognizing place & Degree & 4.05 & 0.53 & 4.12 & 0.87 & 0.65 \\
\hline $\begin{array}{l}\text { Recognizing the } \\
\text { wide jump distance }\end{array}$ & Degree & 94.62 & 0.22 & 95.01 & 0.18 & 0.58 \\
\hline $\begin{array}{l}\text { Realizing trends } \\
\text { (Zigzag tires running) }\end{array}$ & $\mathrm{S}$ & 5.06 & 0.28 & 5.13 & 0.62 & 0.61 \\
\hline Forward rolling & Degree & 2.06 & 0.11 & 2.10 & 0.37 & 0.98 \\
\hline Backward rolling & Degree & 2.09 & 0.9 & 2.08 & 0.21 & 0.52 \\
\hline Standing on hands & Degree & 2.04 & 0.21 & 2.06 & 0.58 & 0.14 \\
\hline
\end{tabular}

The value "T" is a tabular at the level of $0.05=1.717$

It is clear from the previous table (1) that there are no statistically significant differences between the averages of the pre measures of the control and experimental groups in the variables in question, indicating the equivalence of the two groups in these variables.

Data collection tools:

Means of data collection

First: The tools and tools used in the research

\begin{tabular}{|l|l|l|l|}
\hline $\begin{array}{l}* \text { Swedish } \\
\text { seats }\end{array}$ & $*$ wooden box & $*$ Mattresses & $\begin{array}{c}* \text { Carpet of } \\
\text { movements ground }\end{array}$ \\
\hline$*$ Grain bags & $*$ Tape measure & $*$ Hoops & $*$ Ruler in centimeter \\
\hline
\end{tabular}

Second: Scale and tests which used in research

Preparation / Manar Shahin 2002 2- The measure of cognitive Attachment (3)

Preparation / Researcher

Attachment (5)

Test the performance of some ground gymnastics skills (forward roll - rolling back hand parking) attached (3).

Proposed Program:
The researcher used the following devices to collect data:

-Resistameter device to measure length in centimeters.

-The medical balance of weight in kilograms.

-Measuring tape for measuring distances.

-Stopwatch to calculate time.

The following tools were also used in the application of the proposed

program: 
their names indicated in Annex (1) so that the components of the program can be determined in proportion to the Sunni stage for children, And with the type of disability, and in light of their abilities and needs.

\section{Program Goals:}

The program aims to:

-Improving the level of awareness of the visual sense of the disabled child.
-Improve the performance of some skills in the ground gymnastics of the visually impaired child.

Duration of the proposed program:

The total number of units of the program was (16) units of facility (5), and the time of the unit (50) was fifty minutes, as follows:

\begin{tabular}{|c|c|}
\hline$(r \cdot) \mathrm{m}$ & Small games \\
\hline$(r \cdot) \mathrm{m}$ & - Gymnastics games ground. \\
\hline$(1 \cdot) \mathrm{m}$ & Relaxation \\
\hline$(0 \cdot) \mathrm{m}$ & Total time \\
\hline
\end{tabular}

View and discuss the results:

Table (2)

"The significance of the differences between the pre and post measurement in the level of cognitive sense and the dynamics of gymnastics in visually impaired children experimental research group" $\mathbf{N}=10$

\begin{tabular}{l|c|c|c|c|c|c|c|c|c}
\hline \hline \multirow{2}{*}{ Variables } & $\begin{array}{c}\text { Unit } \\
\text { measure }\end{array}$ & $\mathbf{M}$ & $\mathbf{E}$ & $\mathbf{M}$ & $\mathbf{E}$ & \begin{tabular}{c} 
Pre measure \\
\cline { 4 - 8 } \\
Between \\
Therage
\end{tabular} & $\begin{array}{c}\text { Post measure } \\
\text { rate }\end{array}$ & $\begin{array}{c}\text { Differences } \\
\text { valve }\end{array}$ & $\begin{array}{c}\text { Significances } \\
\text { level }\end{array}$ \\
\hline \hline $\begin{array}{l}\text { ( Realize the } \\
\text { direction } \\
\text { (walk in the } \\
\text { corridor) }\end{array}$ & No & 4.25 & 0.39 & 7.58 & 0.33 & 3.33 & $43.93 \%$ & 3.28 & Indicated \\
\hline Stability test & Time & 0.302 & 0.52 & 0.450 & 0.41 & 0.148 & $32.88 \%$ & 3.21 & Indicated \\
\hline $\begin{array}{l}\text { Recognizing } \\
\text { the direction } \\
\text { of the body } \\
\text { during } \\
\text { movement }\end{array}$ & No & 3.44 & 0.21 & 6.95 & 0.18 & 3.51 & $50.50 \%$ & 3.28 & Indicated \\
\hline $\begin{array}{l}\text { Recognizing } \\
\text { body } \\
\text { movement }\end{array}$ & No & 4.65 & 0.14 & 7.75 & 0.11 & 3.10 & $40.00 \%$ & 3.62 & Indicated \\
\hline $\begin{array}{l}\text { Recognizing } \\
\text { place }\end{array}$ & Degree & 4.05 & 0.53 & 7.45 & 0.44 & 3.40 & $45.63 \%$ & 3.15 & Indicated \\
\hline $\begin{array}{l}\text { Recognizing } \\
\text { the wide } \\
\text { jump } \\
\text { distance }\end{array}$ & Degree & 94.62 & 0.22 & 132.28 & 0.18 & 37.66 & $28.46 \%$ & 3.85 & Indicated \\
\hline
\end{tabular}

Follow Table (2)

"The significance of the differences between the pre and post measurement in the level of cognitive sense and the dynamics of Assiut Journal For Sport Science Arts 


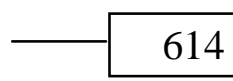

gymnastics in visually impaired children experimental research group" $\mathbf{N}=\mathbf{1 0}$

\begin{tabular}{|c|c|c|c|c|c|c|c|c|c|}
\hline \multirow[b]{2}{*}{ Variables } & \multirow{2}{*}{$\begin{array}{c}\text { Unit } \\
\text { measure }\end{array}$} & \multicolumn{2}{|c|}{ Pre measure } & \multicolumn{2}{|c|}{ Post measure } & \multirow{2}{*}{$\begin{array}{l}\text { Differences } \\
\text { Between } \\
\text { The } \\
\text { average }\end{array}$} & \multirow{2}{*}{$\begin{array}{c}\text { Improvement } \\
\text { rate }\end{array}$} & \multirow{2}{*}{$\begin{array}{c}T \\
\text { valve }\end{array}$} & \multirow{2}{*}{$\begin{array}{c}\text { Significances } \\
\text { level }\end{array}$} \\
\hline & & M & $\mathbf{E}$ & $\mathbf{M}$ & $\mathbf{E}$ & & & & \\
\hline $\begin{array}{l}\text { Realizing } \\
\text { trends } \\
\text { (Zigzag } \\
\text { tires } \\
\text { running ) }\end{array}$ & $S$ & 5.06 & 0.28 & 3.48 & 0.11 & 1.58 & $31.22 \%$ & 3.21 & Indicated \\
\hline $\begin{array}{l}\text { Forward } \\
\text { rolling }\end{array}$ & Degree & 2.06 & 0.11 & 4.10 & 0.12 & 2.04 & $49.75 \%$ & 3.98 & Indicated \\
\hline $\begin{array}{l}\text { Backward } \\
\text { rolling }\end{array}$ & Degree & 2.09 & 0.9 & 3.88 & 0.32 & 1.79 & $46.13 \%$ & 3.21 & Indicated \\
\hline $\begin{array}{l}\text { Standing on } \\
\text { hands }\end{array}$ & Degree & 2.04 & 0.21 & 3.17 & 0.14 & 1.13 & $35.64 \%$ & 3.28 & Indicated \\
\hline
\end{tabular}

*Tabular value at the significance level $(0.05)=1.796$

Table (2) shows that there

are statistically significant differences between the averages of the pre and post me asurements at the level of cognitive perception and the

Table (3)

"The significance of the differences between the pre and post measurement in the level of cognitive sense and mobility of gymnastics in children with visual impairment control group research"N $=10$

\begin{tabular}{|c|c|c|c|c|c|c|c|c|c|}
\hline \multirow[b]{2}{*}{ Variables } & \multirow{2}{*}{$\begin{array}{c}\text { Unit } \\
\text { measure }\end{array}$} & \multicolumn{2}{|c|}{ Pre measure } & \multicolumn{2}{|c|}{ Post measure } & \multirow{2}{*}{$\begin{array}{c}\text { Differences } \\
\text { Between } \\
\text { The } \\
\text { average }\end{array}$} & \multirow{2}{*}{$\begin{array}{c}\text { Improvement } \\
\text { rate }\end{array}$} & \multirow{2}{*}{$\begin{array}{c}\mathrm{T} \\
\text { valve }\end{array}$} & \multirow{2}{*}{$\begin{array}{c}\text { Significances } \\
\text { level }\end{array}$} \\
\hline & & M & E & M & E & & & & \\
\hline $\begin{array}{l}\text { ( Realize the } \\
\text { direction } \\
\text { (walk in the } \\
\text { corridor) }\end{array}$ & No &  & 0.69 & $\overline{5.45}$ & 0.55 & 1.24 & $22.75 \%$ & 2.17 & Indicated \\
\hline Stability test & Time & 0.288 & 0.34 & 0.350 & 0.18 & 0.062 & $17.71 \%$ & 2.36 & Indicated \\
\hline $\begin{array}{l}\text { Recognizing } \\
\text { the direction } \\
\text { of the body } \\
\text { during } \\
\text { movement }\end{array}$ & No & 3.75 & 0.17 & 4.45 & 0.10 & 0.70 & $15.73 \%$ & 2.14 & Indicated \\
\hline $\begin{array}{l}\text { Recognizing } \\
\text { body } \\
\text { movement }\end{array}$ & No & 4.78 & 0.33 & 5.69 & 0.28 & 0.91 & $15.99 \%$ & 2.63 & Indicated \\
\hline $\begin{array}{l}\text { Recognizing } \\
\text { place }\end{array}$ & Degree & 4.12 & 0.87 & 5.94 & 0.45 & 1.82 & $30.63 \%$ & 2.51 & Indicated \\
\hline
\end{tabular}

Follow Table (3)

"The significance of the differences between the pre and post measurement in the level of cognitive sense and mobility of

Assiut Journal For Sport Science Arts 


\section{5}

\section{gymnastics in children with visual impairment control group}

research"N $=10$

\begin{tabular}{|c|c|c|c|c|c|c|c|c|c|}
\hline \multirow[b]{2}{*}{ Variables } & \multirow{2}{*}{$\begin{array}{c}\text { Unit } \\
\text { measure }\end{array}$} & \multicolumn{2}{|c|}{ Pre measure } & \multicolumn{2}{|c|}{ Post measure } & \multirow{2}{*}{$\begin{array}{c}\text { Differences } \\
\text { Between } \\
\text { The } \\
\text { average }\end{array}$} & \multirow{2}{*}{$\begin{array}{l}\text { Improvement } \\
\text { rate }\end{array}$} & \multirow{2}{*}{$\begin{array}{c}\mathrm{T} \\
\text { valve }\end{array}$} & \multirow{2}{*}{$\begin{array}{c}\text { Significances } \\
\text { level }\end{array}$} \\
\hline & & M & E & M & $\mathrm{E}$ & & & & \\
\hline $\begin{array}{l}\text { Recognizing } \\
\text { the wide } \\
\text { jump } \\
\text { distance }\end{array}$ & Degree & 95.01 & 0.18 & $\bar{~} 110.02$ & 0.15 & 15.01 & $13.64 \%$ & 2.29 & Indicated \\
\hline $\begin{array}{l}\text { Realizing } \\
\text { trends } \\
\text { (Zigzag } \\
\text { tires } \\
\text { running ) }\end{array}$ & S & 5.13 & 0.62 & 4.90 & 0.51 & 0.23 & $4.48 \%$ & 2.51 & Indicated \\
\hline $\begin{array}{l}\text { Forward } \\
\text { rolling }\end{array}$ & Degree & 2.10 & 0.37 & 2.98 & 0.12 & 0.88 & $29.53 \%$ & 2.62 & Indicated \\
\hline $\begin{array}{l}\text { Backward } \\
\text { rolling }\end{array}$ & Degree & 2.08 & 0.21 & 2.67 & 0.17 & 0.59 & $22.09 \%$ & 2.45 & Indicated \\
\hline $\begin{array}{l}\text { Standing on } \\
\text { hands }\end{array}$ & Degree & 2.06 & 0.58 & 2.55 & 0.32 & 0.49 & $19.21 \%$ & 2.28 & Indicated \\
\hline
\end{tabular}

*Tabular value at the significance level $(0.05)=1.796$

Table (3) shows statistically significant differences between the averages of the pre and post measurements at the level of cognitive perception and the

Table (4)

gymnastics skills of the blind movements in the study sample where the value of $(\mathrm{T})$ is greater than its tabular value at the level of significance $(0.05)$ for the benefit of telemetry.

Significance of differences between the two dimensions in the level of cognitive perception And gymnastics skills of visually impaired children $(\mathbf{N} 1=$ n $2=10)$

\begin{tabular}{|c|c|c|c|c|c|c|c|}
\hline \multirow[t]{2}{*}{ Variables } & \multirow{2}{*}{$\begin{array}{c}\text { Unit } \\
\text { measure }\end{array}$} & \multicolumn{2}{|c|}{$\begin{array}{l}\text { Experimental } \\
\text { group }\end{array}$} & \multicolumn{2}{|c|}{$\begin{array}{l}\text { Control } \\
\text { group }\end{array}$} & \multirow[t]{2}{*}{$\begin{array}{c}\mathbf{T} \\
\text { valve }\end{array}$} & \multirow[t]{2}{*}{$\begin{array}{c}\text { Significances } \\
\text { level }\end{array}$} \\
\hline & & $\mathrm{M}$ & $\mathrm{E}$ & & & & \\
\hline $\begin{array}{l}\text { Realize the } \\
\text { direction (walk } \\
\text { in the corridor) }\end{array}$ & No & 7.58 & 0.33 & 5.45 & 0.55 & 3.28 & Indicated \\
\hline Stability test & Time & 0.450 & 0.41 & 0.350 & 0.18 & 3.21 & Indicated \\
\hline $\begin{array}{l}\text { Recognizing the } \\
\text { direction of the body } \\
\text { during movement }\end{array}$ & No & 6.95 & 0.18 & 4.45 & 0.10 & 3.18 & Indicated \\
\hline
\end{tabular}

Follow Table (4) 
Significance of differences between the two dimensions in the level of cognitive perception And gymnastics skills of visually impaired

$$
\text { children }(\mathrm{N} 1=\mathrm{n} 2=10)
$$

\begin{tabular}{l|c|c|c|c|c|c|c}
\hline \hline \multirow{2}{*}{ Variables } & \multirow{2}{*}{$\begin{array}{c}\text { Unit } \\
\text { measure }\end{array}$} & \multicolumn{2}{|c|}{$\begin{array}{c}\text { Experimental } \\
\text { group }\end{array}$} & \multicolumn{2}{c|}{$\begin{array}{c}\text { Control } \\
\text { group }\end{array}$} & \multirow{2}{*}{$\begin{array}{c}\text { v } \\
\text { valve }\end{array}$} & $\begin{array}{c}\text { Significances } \\
\text { level }\end{array}$ \\
\cline { 5 - 7 } & $\mathrm{M}$ & $\mathrm{E}$ & & & & \\
\hline \hline $\begin{array}{l}\text { Recognizing } \\
\text { body } \\
\text { movement }\end{array}$ & No & 7.75 & 0.11 & 5.69 & 0.28 & 3.68 & Indicated \\
\hline $\begin{array}{l}\text { Recognizing } \\
\text { place }\end{array}$ & Degree & 7.45 & 0.44 & 5.94 & 0.45 & 3.94 & Indicated \\
\hline $\begin{array}{l}\text { Recognizing } \\
\text { the wide jump } \\
\text { distance }\end{array}$ & Degree & 132.28 & 0.18 & 110.02 & 0.15 & 3.24 & Indicated \\
\hline $\begin{array}{l}\text { Realizing } \\
\text { trends } \\
\text { (Zigzag tires } \\
\text { running })\end{array}$ & $\mathrm{S}$ & 3.48 & 0.11 & 4.90 & 0.51 & 3.59 & Indicated \\
\hline $\begin{array}{l}\text { Forward } \\
\text { rolling }\end{array}$ & Degree & 4.10 & 0.12 & 2.98 & 0.12 & 3.62 & Indicated \\
\hline $\begin{array}{l}\text { Backward } \\
\text { rolling }\end{array}$ & Degree & 3.88 & 0.32 & 2.67 & 0.17 & 3.15 & Indicated \\
\hline $\begin{array}{l}\text { Standing on } \\
\text { hands }\end{array}$ & Degree & 3.17 & 0.14 & 2.55 & 0.32 & 3.87 & Indicated \\
\hline \hline
\end{tabular}

*Tabular value at the significance level $(0.05)=1.796$

Table

(4)

statistically

differences

between

significant

averages of the two dimensions in the experimental and control groups at the level of the skill and mobility skills and the gymnastics skills of the blind movements in the sample. The value of $(\mathrm{T})$ was greater than the tabular value at the significance level (0.05) For the experimental research group.

\section{Discussion of results}

Table (2) shows that there are statistically significant differences between the averages of the pre and post measurements at the level of cognitive perception and the gymnastics skills of the blind movements in the sample. The value of $(T)$ is greater than the 
tabular value at the significance level (0.05) Researcher to the proposed program using the skills of orientation and movement, which contributed to the improvement of some skills on the ground movements.

Abdul-Muttalib al-Qaraiti (2005) points out that visual impairment changes the mental life of the individual in general and that the lack of social adaptation suffered by the visually impaired, which in turn increases his level of psychological anxiety, is due to his visual and intellectual isolation (52: 7)

In the view of Ihab Hamed (2011) that the loss of sight in the first period of life affects the disabled loss of selfconfidence and lack of sense of security and then isolation and inwardness. (62: 3)

The results of this study agree with the study of "Awatif Mohammed, Manal Abdel Fattah (2006)" (8), which referred to the positive impact of motor sports activities on visually impaired children.

Farouk Al-Rousan (2001) noted that movement and activity are the basic form of life and that movement is the main way of expressing ideas and concepts and about the self in general and movement is the oldest forms of communication and emotional participation because of its positive effect in improving the level of physical and physical fitness of the visually impaired. (56: 9)

Najla Fathi (2011) also points out that visually impaired people are considered to be the category that has suffered and continues to suffer from the deprivation of enjoyment of life with the normal, because the sense of sight is a means of recognizing the human being in the social environment, Environment based on visual (95:11)

The researcher believes that the ground movements are the basic basis for the exercise of gymnastics, where the individual begins to learn at an early age if compared to the age and age of education for the rest of the gymnastics, they are the boot and the number of the individual to play on the devices, we find that the nature of work and motor performance on the devices are the same nature of performance On the ground, and this is one of the most important reasons that contributed to the researcher 's choice of ground skills to fit with the 
characteristics of the sample and especially that they are blind.

Thus, the first hypothesis of the research, which states that there are statistically significant differences between the averages of the pre and post measurements in the level of sensory perception and some kinetic skills in the ground gymnastics of the blind children of the experimental research group.

Table (3) shows that there are statistically significant differences between the averages of the pre and post measurements at the level of the sense scale and the gymnastics skills of the blind movements in the research sample where the value of $(T)$ is greater than its tabular value at the level of significance (0.05) This is the result of traditional activities that the family or kindergartens try to provide to the blind child.

Najla al-Sayyid (2006) pointed out that when educating the disabled, they must be transferred to the general society, so they must be taught some of the life skills necessary to enter this society. (11:12)

Jaco (2013) agrees that the visual disability has negative effects on the adaptation of the visually impaired. The fact that blindness does not explain the physical, social and psychological difficulties of the visually impaired is the most important factor. (37:19) (5:12) The same individual and his relationship with society and his directions towards him.

Thus, the second hypothesis was achieved. There are statistically significant differences between the averages of the pre and post measurements in the level of cognitive perception of some motor skills in the ground gymnastics of blind children.

Table (4) shows that there are significant differences between the averages of the two dimensions in the experimental and control groups at the level of cognitive perception and gymnastics skills of the blind movements in the sample. The value of $(T)$ was greater than the tabular value at the significance level (0.05) For the experimental research group, the researcher returns that result to the proposed program using orientation and movement skills, and 1 has directly contributed to improving motor skills on the ground movement device.

This is consistent with Thompson (2001), (23), Samar Helicer (2005), and (6) Hegner 
Hanger (2002) (17) that the use of motor programs in visually impaired children leads to improved orientation and movement skills than their peers. Achieves the third hypothesis.

The researcher believes that the exercise of gymnastics helps to increase awareness of the body and awareness of the movement and also develop the spirit of collective performance, improve the basic skills and develop the senses, as well as they develop the psychological and mental and social characteristics and increase the characteristic of courage and vigilance and accuracy, and lead to a sense of fun and fun, And the movement in their development.

Thus, the third hypothesis of the research was achieved, which states that there are statistically significant differences between the two dimensions of the two dimensions of the experimental and control groups in the level of sensory perception and some kinetic skills in the ground gymnastics of blind children and for the experimental research group.

\section{Conclusions}

-The effect of using the proposed program for the skills of orientation and movement on improving the level of perception of the sense of movement on the ground movements of the blind.

-The effect of using the proposed program for the skills of orientation and movement on the performance of some of the motor skills on the ground movements of the blind.

-The effect of the proposed program on orientation and movement skills is better than the skills acquired for the child in improving the skills of orientation and movement and learning some skills on the ground movements.

\section{Recommendations}

-Guided by the proposed program of orientation skills and movement because of its positive impact on the gymnastics skills of the blind.

-Expanding the programs of the Games because of their positive psychological and physical impact of the blind.

-Conducting training courses for female gymnasts and gymnasts on how to implement mobility programs for disabled people.

\section{References}

\section{1-Abdul Muttalib Al-Qaraiti} (2005): Psychology of children with special needs and their 
upbringing - Arab Thought House - Cairo.

2-Ahmed Mohamed Ali Adam (2008): "The impact of the lessons of physical education proposed to improve the sense of hearing and motor orientation of blind students." Unpublished $\mathrm{PhD}$ thesis. Faculty of Physical Education for Boys in Haram. Helwan University.

3-Amin Riad Al-Khouli, Adly Bayoumi (2001): Educational Gymnastics for Young Children, Dar Al-Fikr Al-Arabi, Cairo.

4-Awatif Ibrahim Mohamed, Manal Abdel Fattah (2006): Children with visual disabilities method and method, Dar Al-Fikr Al-Arabi, Cairo.

5-Auzter, Dacid and others adapted physical Education and Recreation, 7th Edition Mosby Pub, Inc., U.S.A., 2003.

6-Cloudine Sherill: Adapted Physical activity Recreation and spart cross, Disapility, New York; 2001. vol 41. N. 3. p. 3033

\section{7-Gillinson, S., Lownsbrough,} H., \& Thomas, G. (2004). Survival skills final: using life skills to tackle social exclusion. United Kingdom: Demos \& Crisis.

8- Emerson, Robert S orientation and Mobility Content for Children and Youths Journal of Visual Impairment \& Blindness. Vol.100(6), Jun 2006 9- Hegner. D.: Life skills a cross, the curriculum combined teacher, student manual Department of general Academic Education, country of publeshing U.S, New Jersy; 1992. p. 15-22.

10-Huebner, K, Wiener, W. (2005). Guest editorial. journal of idea97 final regulations 1997 Amendments to the Individuals with disabilities education act of 1997, 34cfr part 300.24(b) 6,Assistance states for the education of Children with disabilities.

\section{1- Ihab Hamid Al-Beblawi} (2011): orientation and movement skills for the blind Dar Al-Zahraa - Riyadh, Saudi Arabia.

\section{2- Jacko Author، Virginia A:} Blind Babies Play Program model for affordable, sustainable early childhood literacy intervention through play and socialization. urnal of Visual Impairment \& Blindness. Vol.107 (3), May-Jun 2013

13- Khawla Ahmed Yahya (2011): Educational programs for individuals with special needs- Dar Al-Masirah for publication, 2, Amman.

14- Mona Sayed Al-Baroudi (2008): "The Effect of Exercise 
Program on the Use of Instruments on Some Cognitive Sensory Variables of the Blind", Journal of Sports Sciences, Faculty of Physical Education, Minia University.

15- Nader Ahmed Jaradat (2010): "The Effectiveness of Sensory Program in Developing the Kinetic Skills of the Blind Child", unpublished PhD thesis, Faculty of Education, Department of Special Education, Hail University, Saudi Arabia.

16- Najla Al-Sayed (2006): "Effectiveness of a proposed educational program for the integrated experiences of the blind child in kindergartens, $\mathrm{PhD}$ thesis, Faculty of Pediatrics, Cairo University.

17- Najla Fathi Khalifa (2002): "Proposed motor education program for the development of basic motor skills for visually impaired children, pre-school, master's thesis, Faculty of Physical Education for Girls, Alexandria University.

18- Notori, S. \& Others: Putting Real-Life Skills Into LEP/IFSPS for Infants and
Young Children, Journal of Teaching Exceptional Children Vol.27, No.2, 1995. By Eric EJ494798.

19- Said Mohammed Al-Saeed (2006): Special education programs and their curricula between thought and application and development, World of Books, Cairo.

20-Samar Al-Yaseer (2005): Blindness and vision difficulties, Al- Furat Publishing, Cairo.

21-Signorelli, V.A.: Daily living and physical Education skills for Elementary Mild Retarded pupils, Los Anglos City Schools, instrucational programs, Branch 2005 p. 327

22- Singh, N. (2004): Understanding life skills. Hamburg: UNESCO Institute for Education.RetrievedOct8, 2004

23- Thampson. E.C: the effects of An Enseruice training program for Regular classroom teaches of self for Disabld and educable Mentally students 2001 vol. 43, N. 13 p. 76-79.

24- UNESCO. (2007): EFA National report from 2001 to 2005. Bangladesh: UNESCO 